\title{
Optical Features of the Black Sea Aerosol and the Sea Water Upper Layer Based on In Situ and Satellite Measurements
}

\author{
V.V. Suslin ${ }^{1}$, V.K. Slabakova ${ }^{2}$, D.V. Kalinskaya ${ }^{1}$, S.F. Pryakhina ${ }^{1}$, \\ N.I. Golovko ${ }^{1}$ \\ ${ }^{1}$ Marine Hydrophysical Institute, Russian Academy of Sciences, Sevastopol, Russian Federation \\ e-mail: slava.suslin@gmail.com \\ ${ }^{2}$ Institute of Oceanology BAS, Varna, Bulgaria
}

\begin{abstract}
The article gives the analysis of the quality of reconstructing basic aerosol characteristics (the aerosol optical depth AOD and the Ångström parameter $\AA$ ) and the water-leaving radiance spectrum (normalized water-leaving radiance $n L w$ ) resulted from application of standard atmospheric correction of satellite measurements data on the ascending over the Black Sea radiance obtained by the ocean color scanners MODIS-Aqua/Terra and VIIRS-SNPP. The analysis basis consists of the in situ measurements carried out at the AERONET and AERONET-OC stations synchronously with the satellite ones.

Joint analysis of simultaneous field and satellite measurement data reveals the problems in correct description of basic optical parameters of the Black Sea aerosol when the aerosol models are applied for standard atmospheric correction. A «compensation» effect (i.e. negative slope of the difference relation within AOD and $\AA$ for in situ and satellite data) is demonstrated, and its influence upon quality of standard atmospheric correction is assessed. It is shown that for the current version of atmospheric correction, the absolute $n L w$ values turn out to be understated as compared to the in situ measurements. The result closer to the in situ data can be obtained by normalizing the satellitederived $n L w$ spectrum on its value in the $490 \mathrm{~nm}$ band.
\end{abstract}

Keywords: AERONET, ocean color scanners, quality of atmospheric correction, the Black Sea.

DOI: 10.22449/1573-160X-2016-1-20-32

(c) 2016, V.V. Suslin, V.K. Slabakova, D.V. Kalinskaya, S.F. Pryakhina, N.I. Golovko

(C) 2016, Physical Oceanography

Introduction. Over the last $10-20$ years due to the rapid development of observing systems, including in situ [1 - 5] and the satellite ones [6, 7], long-term data series about the parameters that characterize the properties of atmospheric aerosol: the aerosol optical depth ( $\tau$, or $A O D)$ and the Ångström parameter $(\alpha$, or $\AA$ ) has been accumulated. Both of these characteristics are the key ones when performing atmospheric correction of upwelling radiance, registered above the water surface by the satellite devices $[8,9]$. Therefore, the accuracy of normalized water-leaving radiance $(n L w)$ [10] and depends on the accuracy of the AOD and $\AA$ values. Quantitative characteristics of this spectrum will enable to find the solution of a number of new important and interesting problems, for instance, the recovery of the species composition of phytoplankton from satellite multispectral measurements of the ocean-atmosphere system upwelling radiance [11, 12]. Due to the inland geographical position of the Black Sea and its isolation from the World's Ocean aerosol properties of the Black Sea may differ significantly from the properties of the ocean. [13] So, one of the aims of our research was to determine 
the aerosol type, characteristic for the Earth's atmosphere, according to its optical parameters, the Black Sea aerosol relates to on the basis of in situ measurements of AERONET stations (AErozol RObotic NETwork).

Earlier, [14] demonstrated a comparative analysis of the two-dimensional histogram AOD and $\AA$ of the Black Sea aerosol on two separate samples, consisting either of the satellite data, either of the measurement data of the Sevastopol AERONET station. In this work it was shown that the quality of the satellite data recovery on AOD and $\AA$ was affected by specular component from the water-air interface and that the best average result in the sense of the accuracy of recovery of the AOD values was achieved at the wavelength of about $500 \mathrm{~nm}$. However, since the publication of the article [14], several version upgrades of satellite data was carried out [15]. Due to the aforementioned events, the second aim was to study the quality of the satellite data on AOT and $\AA$ for the current processing version. To solve this problem, in the present work we compared the optical characteristics of the Black Sea aerosol obtained synchronously on the measurement data at the AERONET station and corresponding satellite data. The results of this analysis are directly related to the spectrum reconstruction quality $n L w$. Hence, there appears the third aim - the comparison of the values of in situ measurements and the $n L w$ spectrum satellite data under the controlled quality of the recovery of the Black Sea aerosol optical properties.

Data and methods. In the work the data of AERONET stations (level 2.0): on AOD at the wavelength of $870 \mathrm{~nm}$ and $\AA$ for two spectral intervals $440-870$ and $380-500 \mathrm{~nm}$ were applied. Values of the parameters are calculated by means of Direct Sun Algorithm [16]. Information on the station is shown in Tab. 1. In addition, for special occasions, the data of model calculations of backward trajectories of the air masses $[17,18]$ for the Sevastopol AERONET station was applied [1].

The $2^{\text {nd }}$ level current version atmospheric satellite data on AOD and $\AA$ for two devices MODIS and VIIRS from Aqua, Terra and SNPP satellites were used to create the data sample synchronous with respective measurements on the three Black Sea AERONET stations: Galata, Gloria and Sevastopol (see Tab. 1). Beforehand the data processing of the Black Sea daily survey was carried out. It consisted of two stages. The first stage was the rejection of all $2^{\text {nd }}$ level satellite data taking into consideration the following masks: glint, high degree polarization, stray light, coccolithophores [19]. In the second stage after the rejection the aforementioned data was interpolated to the grid with the step at latitude $0.025^{\circ}$ and at longitude $0.035^{\circ}$. Synchronous data sample consisted of only those measurements which do not differ in time by more than 5 minutes. For atmospheric 
satellite data a neighborhood of two mesh points $( \pm 6 \mathrm{~km})$ from the AERONET station location, which AOD and $\AA$ average values were calculated for, was considered. Besides, on the two Black Sea AERONET and AERONET-OC (AErozol RObotic NETwork-Ocean Color) Gloria and Galata Platforms simultaneously with the measurements of the atmosphere optical parameters measurements of the water upper layer optical propeties were carried out. They included $n L w$ spectrum with the following wavelength centers: 412, 441, 491, 530, 555 and $675 \mathrm{~nm}$ [20, 21]. To solve the third problem, we limited by using measurements carried out at the Gloria Platform, since they contained longer time series in comparison with Galata Platform that had just started to operate. To obtain $n L w$ spectrum on the satellite data a neighborhood of \pm 1 grid node, or $\pm 3 \mathrm{~km}$ was considered.

Table 1

\begin{tabular}{|c|c|c|c|c|}
\hline Platform & $\begin{array}{l}\text { Principle } \\
\text { investigator }\end{array}$ & $\begin{array}{l}\text { Observation } \\
\text { period }\end{array}$ & Latitude & Longitude \\
\hline Tomsk & $\begin{array}{l}\text { B. Holben, } \\
\text { M. Panchenko }\end{array}$ & $\begin{array}{l}24.10 .2002- \\
20.04 .2013\end{array}$ & $56.477^{\circ} \mathrm{N}$ & $85.047^{\circ} \mathrm{E}$ \\
\hline Sevastopol & B. Holben & $\begin{array}{l}\text { 14.05.2006- } \\
30.08 .2013\end{array}$ & $44.616^{\circ} \mathrm{N}$ & $33.517^{\circ} \mathrm{E}$ \\
\hline OPAL & $\begin{array}{l}\text { N. O'Neill, } \\
\text { I. Abboud, } \\
\text { V. Fioletov }\end{array}$ & $\begin{array}{l}01.04 .2007- \\
18.09 .2013\end{array}$ & $79.990^{\circ} \mathrm{N}$ & $85.939^{\circ} \mathrm{W}$ \\
\hline Galata & G. Zibordi & $\begin{array}{l}\text { 12.04.2014- } \\
20.07 .2014\end{array}$ & $43.045^{\circ} \mathrm{N}$ & $28.193^{\circ} \mathrm{E}$ \\
\hline Tahiti & B. Holben & $\begin{array}{l}24.07 .1999- \\
26.10 .2009\end{array}$ & $17.577^{\circ} \mathrm{S}$ & $149.606^{\circ} \mathrm{W}$ \\
\hline Gloria & G. Zibordi & $\begin{array}{l}25.01 .2011- \\
22.02 .2014\end{array}$ & $44.600^{\circ} \mathrm{N}$ & $29.360^{\circ} \mathrm{E}$ \\
\hline $\begin{array}{l}\text { Tamanrasset } \\
\text { INM }\end{array}$ & E. Cuev asas-Agullo & $\begin{array}{l}\text { 30.09.2006 - } \\
08.12 .2012\end{array}$ & $22.790^{\circ} \mathrm{N}$ & $5.530^{\circ} \mathrm{E}$ \\
\hline Manaus & P. Artaxo & $\begin{array}{l}\text { 01.02.2011 - } \\
\text { 28.05.2014 }\end{array}$ & $2.891^{\circ} \mathrm{S}$ & $59.970^{\circ} \mathrm{W}$ \\
\hline
\end{tabular}

Results and discussion. Below, see the results of a comparative analysis of the aerosol parameters over the Black Sea and other areas using only the measurements AERONET stations. This analysis was aimed to find out which of the Earth's atmosphere aerosol types in the AOD and $\AA$ parameters the Black Sea aerosol refers to. For this purpose, in the coordinates $\{\tau(870), \alpha(440-870)\}$ 
several characteristic regions, including the Arctic, Oceania, the equatorial region of tropical forests in Brazil, Sahara Desert, continental Siberia and the Black Sea region have been considered (Tab. 1). The results of this comparison are shown in Fig. 1.

There are four types of aerosol for these stations: arctic, ocean, desert and continental. According to the optical characteristics, the Black Sea aerosol found out to be almost identical to the continental one (Tomsk station). Somewhat unexpected is the result of a match of the continental aerosol characteristics with the aerosol parameters on Manaus station. The only distinguishing feature of the latter is a relatively uniform distribution $\alpha$ for $\tau(870)>0.1$. At the same time, for Tomsk and Sevastopol stations at least bimodal $\alpha$ histogram character $\tau(870)>0.1$ takes place. Fig. 2, $b$ for Sevastopol station reflects this particular property on the example of the $[0.25 ; 0.3]$ subset from the main $\tau(870)$ sample
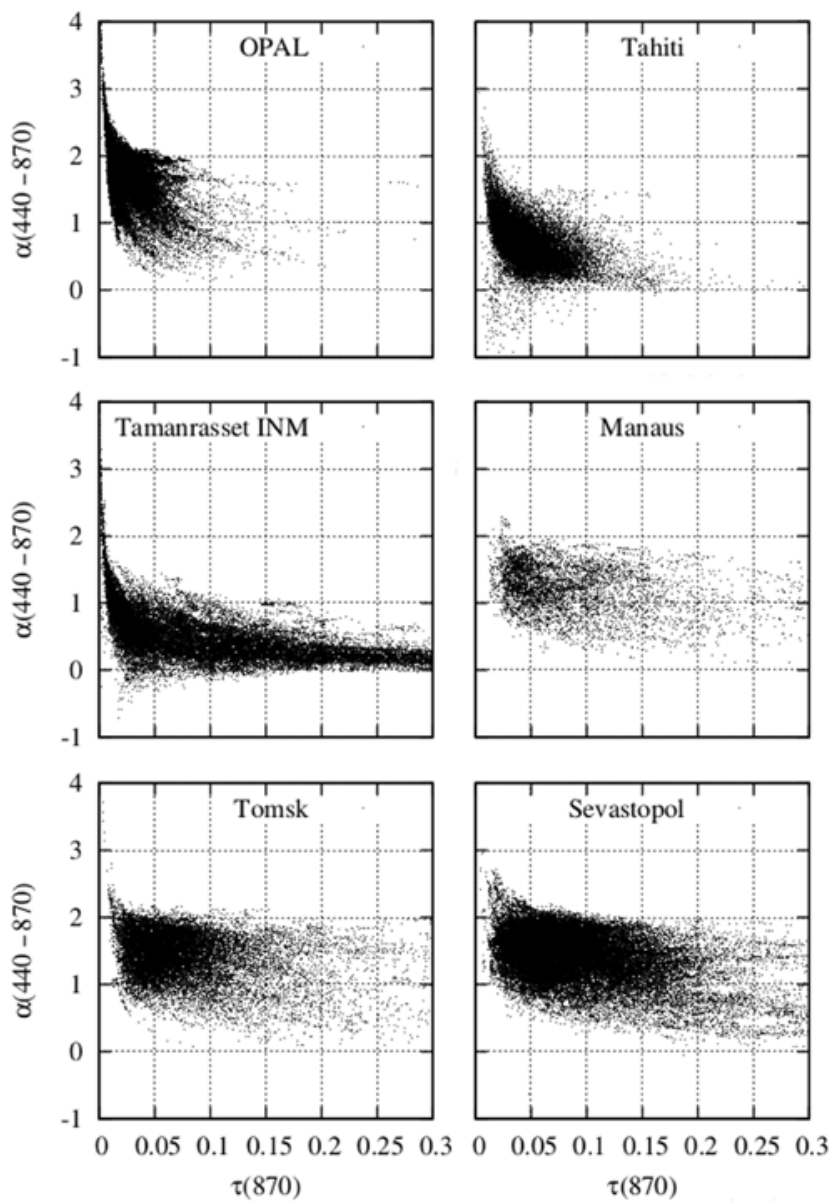

Fig. 1. Relation between the values $\tau(870)$ and $\alpha(440-870)$ within the whole observation period according to the data of AERONET stations for the various regions: OPAL (the Arctic), Tahiti (the Pacific Ocean), Tamanrasset INM (the Sahara desert area), Manaus (the Amazon jungle equatorial region), Tomsk (Siberia), Sevastopol (the Black Sea) 


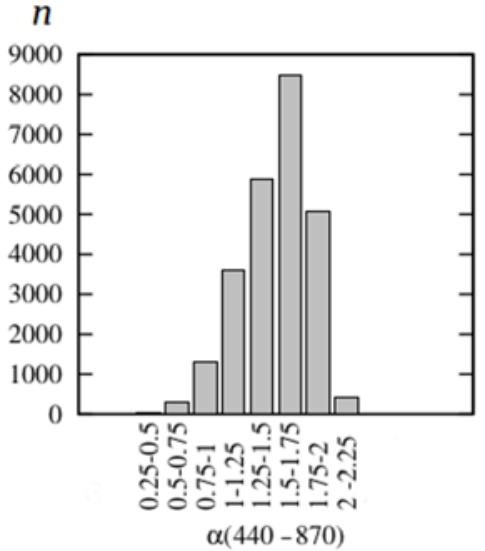

a

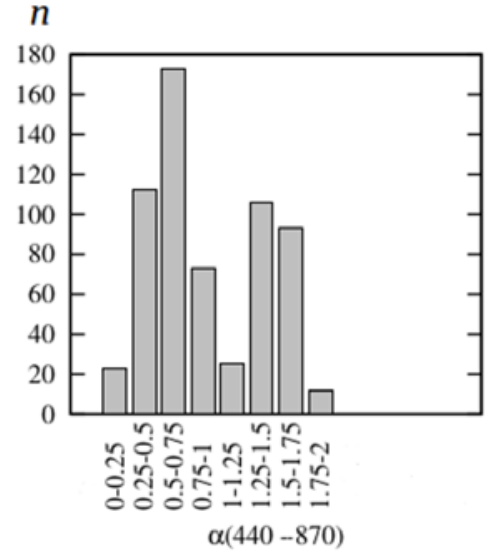

$b$

Fig. 2. Histograms $\AA$ for two AOD samples, obtained according to Sevastopol AERONET station: $a-$ $\tau(870)=[0.05 ; 0.1], N=25117, b-\tau(870)=[0.25 ; 0.3], N=617$ (where $N$ - number of measurements per sample, $n$ - number of measurements)

In order to identify the possible causes of the two-mode $\alpha$ histogram patterns for $\tau(870)>0.1$ two other samples for the two intervals $\alpha$ : [1.5; 2] and [0;0.5] were prepared. Analysis of the three-day data of backward trajectories of air masses for each of these samples showed that high $\AA$ values corresponded to the air masses coming from the north, north-east and north-west and the low $\AA$ values - to the air masses coming from the south: from Turkey, from the Arabian Peninsula and from the Sahara (see Fig. 3).
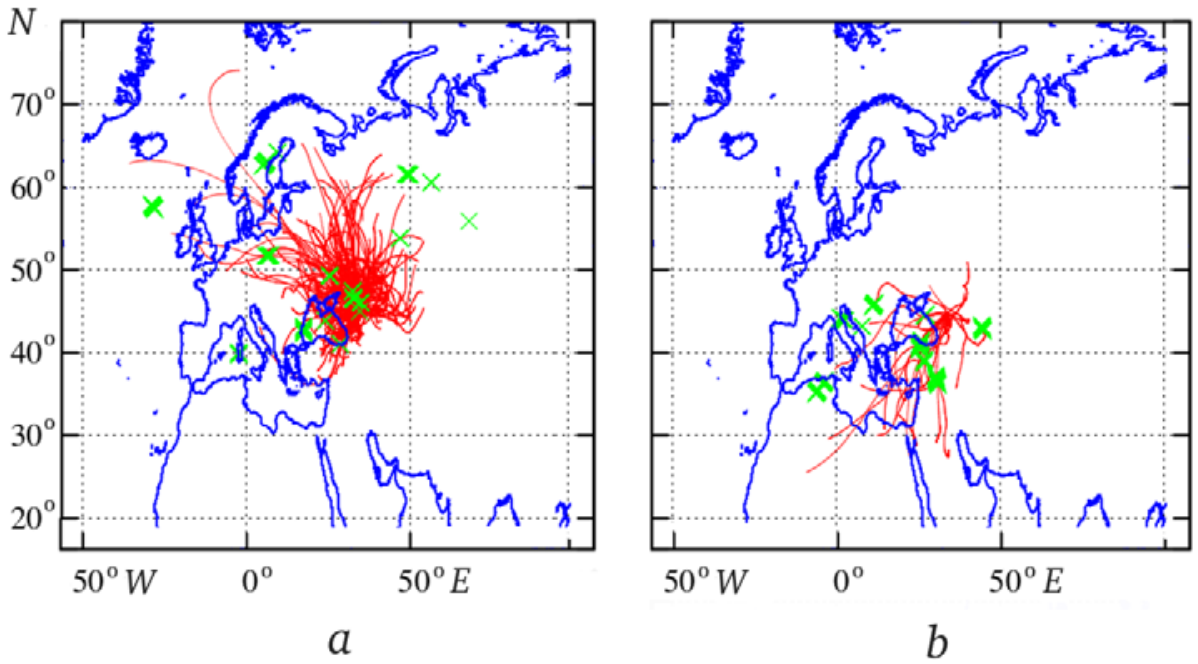

Fig. 3. Routes for the movement of air masses for 800 - 900 mbar (solid line) layer according to the three-day analysis of backward trajectories and location (symbols) of the generation places of heavy lifting air masses from the lower layers of the atmosphere, determined by the method of [22] for the two samples according to the data of Sevastopol AERONET station for $\tau(870)>0.1: a-\alpha=[1.5 ; 2]$, $b-\alpha=[0 ; 0.5]$ 
Another property of the aerosol (the Å value change, depending on the spectral range) is considered in detail. This property is quite essential for the correct choice of the aerosol pattern when performing atmospheric correction. The combined sample of the synchronous measurements permits to analyze the relation between $\alpha(440-870)$ and $\alpha(380-500)$, obtained according to the data of AERONET stations from 8 to 11am GMT, i.e. during the measurements from the satellites over the Black Sea. Criteria for synchronous sampling are described above in the "Initial data and techniques." This relation is interesting from the viewpoint of the $n L w$ spectrum recovery quality. Fig. 4 shows the result of this comparison on the example of the two Black Sea stations. On the one hand, the existence of a dominant communication (elongation along the lines of 1: 1) is obvious. On the other hand, the events occur when deviations from the 1:1 are sufficiently large. Since we are talking only about the in situ measurements, so, if the changes in the $\AA$ parameter spectral variation are not taken into account when performing atmospheric correction, it will certainly lead to the $n L w$ spectrum distortion in the shortwave region.

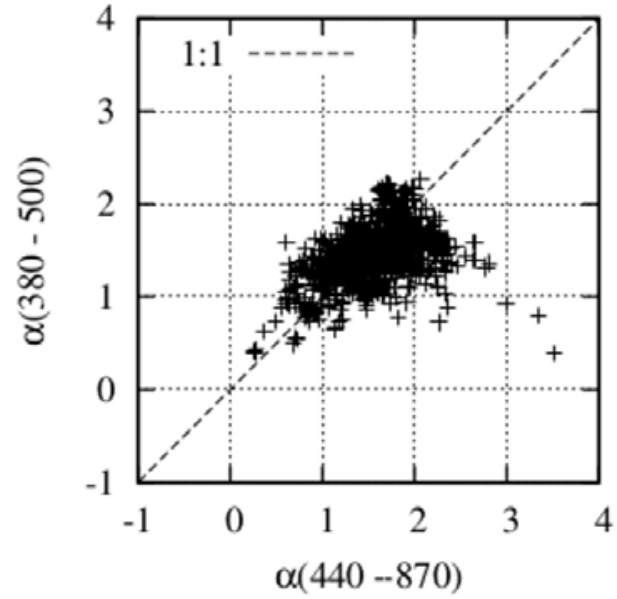

a

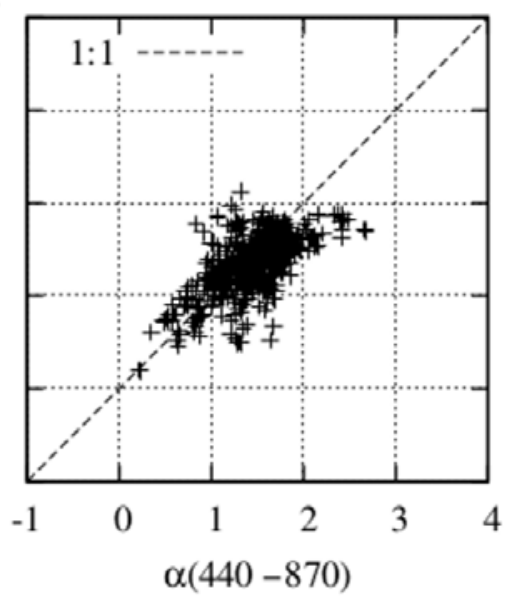

$b$

Fig. 4. Relation within the values $\alpha(440-870)$ and $\alpha(380-500)$ according to the synchronous sample data for AERONET stations: $a$-Sevastopol, $b-$ Gloria

Additional important information was obtained from the analysis of the time series of $\Delta \alpha=\alpha(440-870)-\alpha(380-500)$ difference on the example of Sevastopol station (Fig. 5). Noteworthy is a strong interannual variability, which is the most pronounced for 2011 and 2012 as compared to other years. Whether is it connected with the appearance of some unusual aerosol in the Black Sea or with any other reason? The answer to this question requires a separate study. We note only that the maximum positive $\Delta \alpha$ values, excluding 2011 and 2012 are observed, as a rule, mainly in the summer months, which is probably due to the presence of the absorbing aerosol. In particular, it was confirmed in [22] when analyzing the optical properties of the air masses coming from the areas southward the Black Sea. 


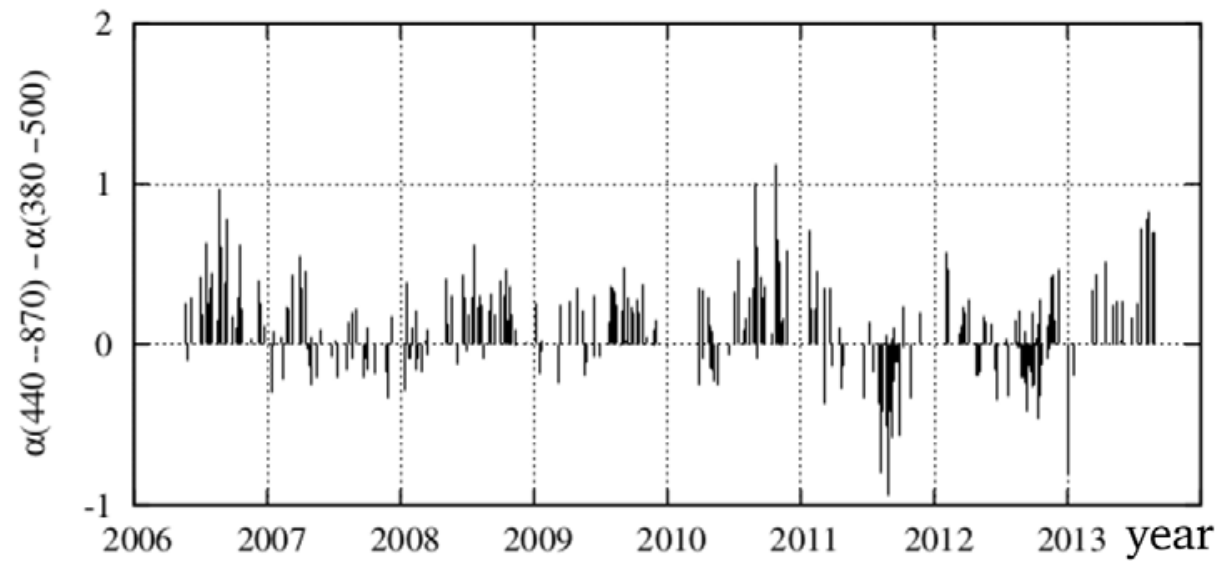

Fig. 5. Interannual and seasonal variability of the difference between the $\alpha(440-870)$ and $\alpha(380-$ 500) values according to the synchronous sample of Sevastopol AERONET station

Results of the comparison of AOD and $\AA$ values obtained according to the data of the satellite and in situ measurements of Sevastopol AERONET station for the combined synchronous sample are shown in Fig. 6. The first thing that attracts attention is overstating of the satellite data for AOD in the majority of cases, compared with its in situ measurements, which can not be explained by the difference in wavelength for this parameter. The second one is the lack of connection between the satellite data in the parameter $\AA$ and its in situ measurements in AERONET station. As for AOD, the similar results were obtained in [23]. The more detailed analysis of this sample shows the existence of a "compensation" of one parameter by the other, i.e. for the overstated AOD satellite values compared with synchronous in situ measurements values the $\AA$ satellite value turns to be understated relating to the measurements of AERONET stations, and vice versa. The negative slope of the linear relation (Fig. 7, a) of the differences of values of the two parameters indicates the "compensation" behavior of the AOT and $\AA$ satellite data with respect to their real values - the measurements in Sevastopol AERONET station. The analysis of the data for the other two stations Black Sea AERONET network - Galata and Gloria (Fig. 7, b) gives the similar result. Regarding such comparisons here and below, it should be mentioned that these results may be influenced by a quasi-synchronous measurements (in this case $<5 \mathrm{~min}$ ) and different spatial scales of the signal averaging at the sea surface (AERONET $-\sim 1 \mathrm{~m}$, the satellite - \pm 2 grid node, or $\pm 6 \mathrm{~km}$ ). 

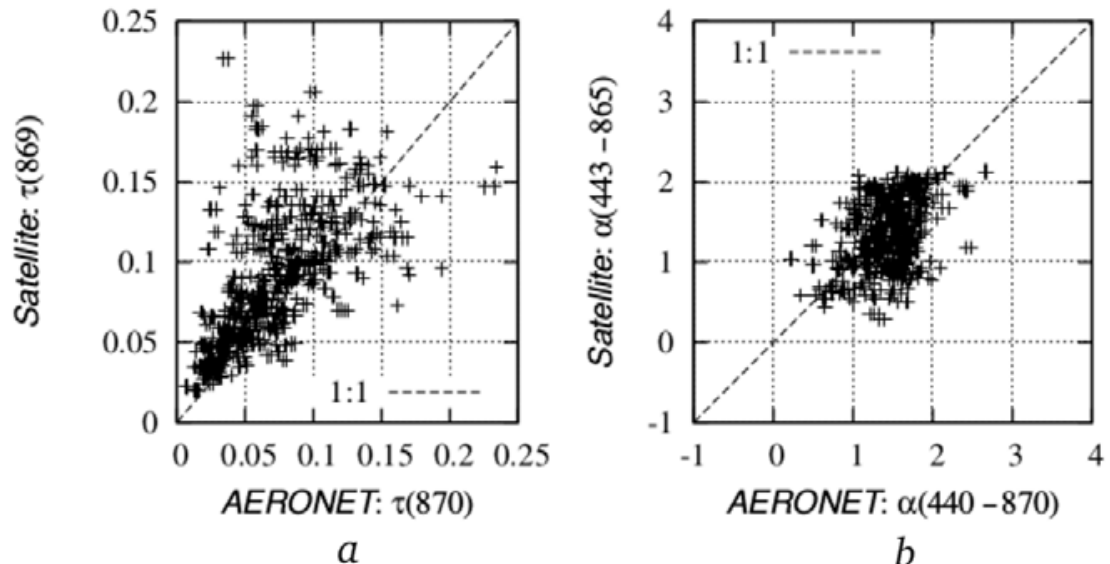

Fig. 6. Relation within AOD $(a)$ and $\AA(b)$ values for synchronous measurements of Sevastopol AERONET station and combined satellite data of MODIS-Aqua/Terra and VIIRS-SNPP ocean color scanners

The result of such a "compensation" effect is as follows: in the region of $500 \mathrm{~nm}$ wavelength the AOD value is close to the in situ measurement data, and therefore the higher accuracy of $n L w$ spectrum recovery in the neighborhood of this wavelength can be expected, that is consistent with the conclusions of [14]. To verify this fact, three special cases of AOT and $\AA$ difference change from combined sample marked in Fig. 7, $b$ by 1,2 and 3 respectively were considered. For these cases the $n L w$ spectra, obtained from satellite data from the neighborhood of \pm 1 grid node (or $\pm 3 \mathrm{~km}$ ) were compared to the in situ measurements in Gloria AERONET-OC station. The result of this comparison is shown in Fig. 8. The specific characteristics of observation conditions these three $n L w$ spectra are shown in Tab. 2.

Table 2

Some initial data characteristics for samples 1, 2 and 3, shown in Fig. 7, $b$

\begin{tabular}{|c|c|c|c|c|c|c|c|}
\hline \multirow{2}{*}{ Sample } & \multirow{2}{*}{ Date } & \multirow{2}{*}{$\begin{array}{c}\text { MODIS } \\
\text { h:min }\end{array}$} & \multirow{2}{*}{$\begin{array}{c}\text { Gloria, } \\
\text { AERONET- } \\
\text { OC } \\
\text { h:min }\end{array}$} & \multicolumn{4}{|c|}{ Gloria, AERONET } \\
\hline & & & & h:min & $\alpha(440-870)$ & $\alpha(380-500)$ & $\tau(870)$ \\
\hline \multirow{3}{*}{1} & 10.08.2012 & T 09:00 & 08:40 & 08:39 & 1.63 & 1.45 & 0.135 \\
\hline & 10.08 .2012 & A $10: 40$ & 11:40 & $10: 54$ & 1.88 & 1.68 & 0.098 \\
\hline & & & & 11:41 & 1.82 & 1.65 & 0.107 \\
\hline 2 & 06.09.2011 & A $11: 10$ & $11: 13$ & $11: 13$ & 1.89 & 1.71 & 0.086 \\
\hline 3 & 08.08.2013 & A 11:25 & $11: 13$ & $11: 13$ & 1.40 & 1.10 & 0.142 \\
\hline
\end{tabular}

Notes: $T$-Terra satellite, $A$-Aqua satellite; the additional information on the sample 1is printed in bold; indicated time - GMT.

PHYSICAL OCEANOGRAPHY NO. 1 (2016) 


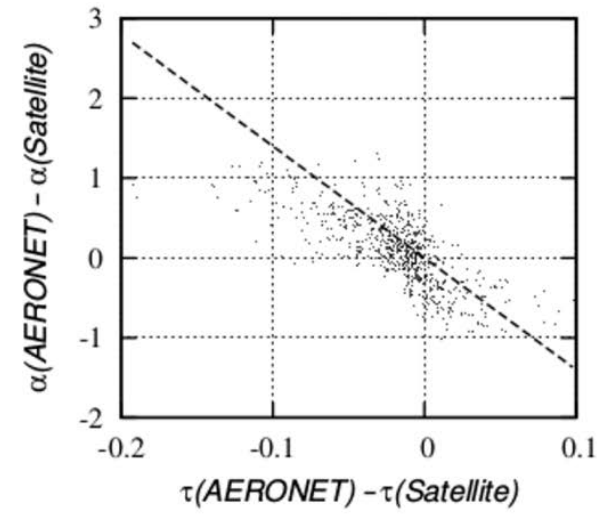

$a$

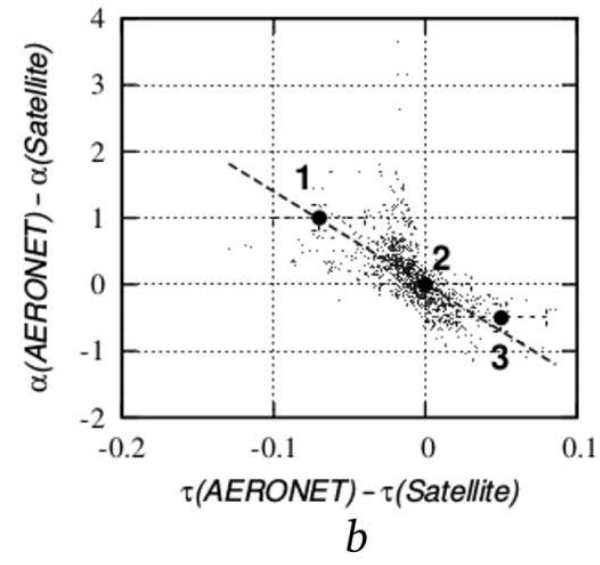

Fig. 7. "Compensation" behavior of the difference within AOT and $\AA$ according to the data of in situ (AERONET: $\alpha(440-870)$ and $\tau(870))$ and satellite (Satellite: $\alpha(443-865)$ and $\tau(869))$ measurements in the synchronous sample during the total observation period in the two AERONET stations: $a-$ Sevastopol, $b$-Gloria (circles are the position of the samples 1, 2 and 3, the joint analysis of the data of $n L w$ spectrum synchronous measurements was performed for in Gloria station and by satellite ocean color scanners)

Note that especially for the case 1 there is no data of the $n L w$ spectrum synchronous ( $<5 \mathrm{~min}$ ) measurements from the satellites and Gloria station. Owing to this case the measurements of Aqua and Terra satellites were considered for the next three closest time measurements of the aerosol optical parameters. The aerosol parameters in a given time interval were stable $(\Delta \alpha>0), n L w$ spectra were also stable according to the satellite data and Gloria station measurements. Therefore, Fig. 8 does not show $n L w$ spectra, corresponding to the data of the sample 1 indicated in bold in Tab. 2. As it was expected, there are differences between the $n L w$ spectra satellite and in situ measurements. Firstly, for the all three samples the values of $n L w$ in situ measurements were systematically overstated as compared with the satellite data. Secondly, the best result was observed in the spectral band (SB) with a central wavelength of $443 \mathrm{~nm}$. Thirdly, the result of the $n L w$ spectra normalization comparison on the corresponding value in the $490 \mathrm{~nm}$ band allows speaking about the good matching of in situ and satellite data. A similar result was obtained earlier in [14]. Note that in all the three cases, in the SB $412 \mathrm{~nm}$ the $\mathrm{nLw}$ spectrum normalized values for direct measurements were higher than the satellite data. In our opinion, this is the result of the fact that $\Delta \alpha>0$, i.e. it is due to a decrease in $\AA$ parameter in the shortwave spectrum part comparing to the longwave one. We suppose that one of the causes of the discrepancy between the data of the in situ and satellite measurements is incorrect description of the optical properties of a real aerosol over the Black Sea by a set of models applied in the 
performance of the standard atmospheric correction [9], namely, when the spectral course variations of $\AA$ parameter during the correction are not taken into consideration.
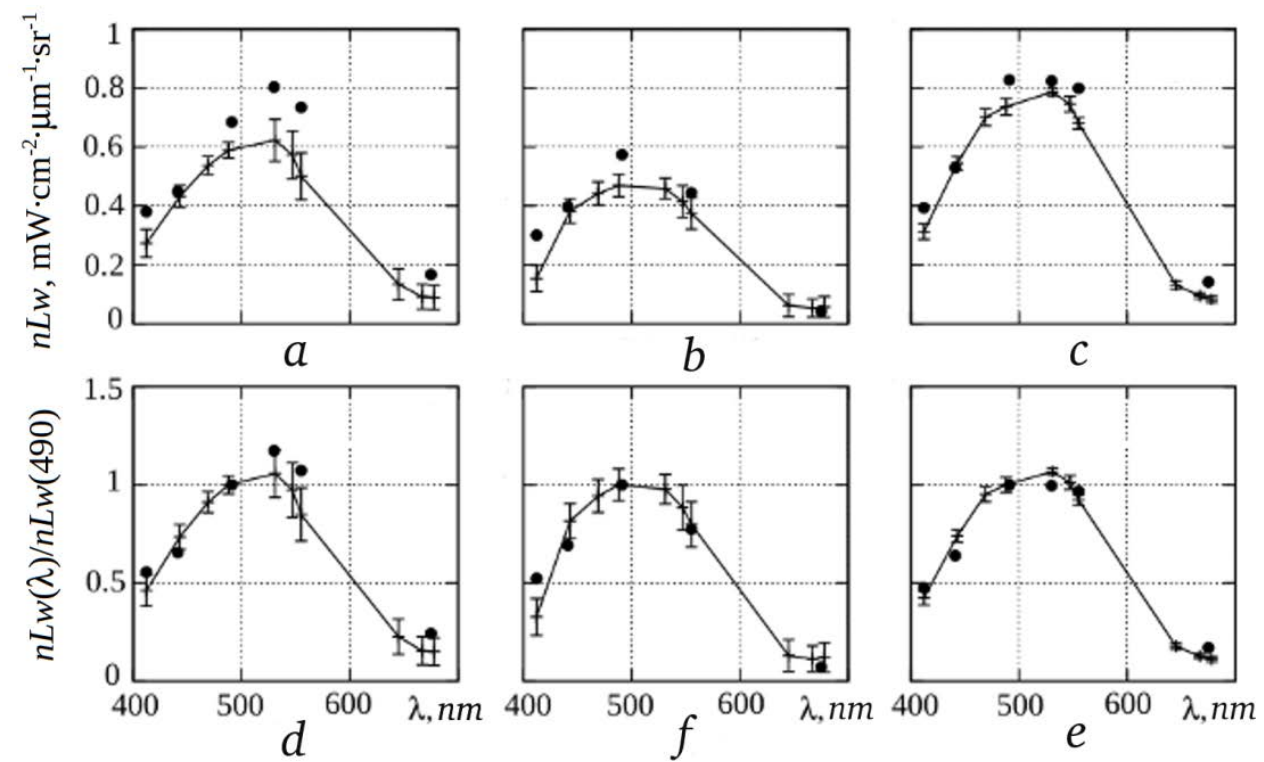

Fig. 8. Results of the comparison of $n L w$ spectra $(a, b, c)$ and their normalization $(d, e, f)$ on the value in the $490 \mathrm{~nm}$ band, obtained in Gloria AERONET-OC station (circles), to the satellite data (solid line) for the three cases, marked in Fig. $7, b$ by numbers $1(a, b), 2(c, d)$ and $3(f, e)$ (the confidence intervals are marked by vertical segments)

Below we are to consider some errors the observed discrepancy between satellite and in situ data can lead to at their further use. The answer to this question depends on the task, where as an input parameter the $n L w$ spectrum normalized radiance or its normalized value data will be used. If we talk about the individual $\mathrm{SB}$, the maximum absolute error is equal to $\sim 0.2 \mathrm{~mW} \cdot \mathrm{cm}^{-2} \cdot \mathrm{mkm}^{-1} \cdot \mathrm{sr}^{-1}$ in the case 1 in the $530 \mathrm{~nm}$ band. In general $n L w$ spectrum integral value of $400-700 \mathrm{~nm}$ leads to a relative error in the $5-10 \%$ band for the three cases considered here.

Another problem can be the recovery of the inherent optical properties such as light absorption coefficient of live $\left(a_{p h}\right)$ and nonliving $\left(a_{C D M}\right)$ matter organic, light backscattering coefficient of by the suspension $\left(b_{b p}\right)$ and the spectral properties of light absorption coefficient by nonliving organic matter $(S)$ and the light backscattering coefficient of by suspension $(n)$. The fact that in Fig. 8 in all the three cases, the normalized satellite $n L w$ spectra in the wavelength band from 490 to $555 \mathrm{~nm}$ (namely, they are used for the calculation in $[24,25]$ ) are close to 
the in situ data, can count on a satisfactory recovery of $a_{p h}$ and $a_{C D M}$, despite the error in the form of a "compensation" effect (Fig. 7). At the same time the calculation of the spectral properties $S$ and $n$ has certain difficulties, when the spectral course variations of $\AA$ parameter are not taken into consideration.

Conclusions. It was demonstrated that the Black Sea aerosol according to its main optical properties such as $\tau(870)$ and $\alpha(440-870)$ is close to the continental one. When AOD values are higher 0,1 the two-mode $\alpha$ histogram pattern takes place. According to the analysis of the backward trajectories of air masses, it is connected with the different aerosol generation regions. Joint analysis of the synchronous data of the in situ and satellite measurements showed the existence of the problem of the correct description of the Black Sea aerosol optical parameters AOD and $\AA$ by a set of aerosol models, used when performing a standard atmospheric correction [9]. Comparing these results with materials of the works [23] and [14], published in 2007 and 2009, accordingly, it can be concluded that the current version of satellite data has the same disadvantages. It is shown that for the current version of atmospheric correction, the absolute $n L w$ values turn out to be understated as compared to the in situ measurements. The result closer to the in situ data can be obtained by normalizing the satellite-derived $n L w$ spectrum on its value in the $490 \mathrm{~nm}$ band.

Acknowledgements. The research was carried out within the framework of the Project Research the Laws of the Marine Environment Condition Changes on the basis of Operational Observations and System Data of the Diagnosis, Forecast and Reanalysis of the Condition of Marine Water Areas (code "Operational oceanography") and under the sponsorship of RFBR (scientific project No. 16-3500179 "Research of the Variability of the Atmosphere Optical Properties over the Black Sea under the Influence of the Sahara Desert Dust Aerosol”). The authors are grateful to the scientists involved in the AERONET, AERONET-OC and $N A S A / G S F C / O B P G$ Projects for presented data and its preliminary processing and also the referee for a number of helpful suggestions for improvement in the article.

\section{REFERENCES}

1. http://aeronet.gsfc.nasa.gov/Site_Lists/aeronet_locations_2014_lev20. txt (Access-October, 2015).

2. Ivanov, A.P., Chaykovskiy, A.P. \& Zege, E.P. [et al.], 2011, “Monitoring protsessov perenosa vzveshennykh $v$ atmosfere chastits po dannym distantsionnykh i lokal'nykh izmereniy $v$ Belarusi i sopredel'nykh regionakh [Monitoring of the transport processes of suspended particles in the atmosphere, according to local and remote measurements in Belarus and neighboring regions], Zbirnik naukovikh statey III Vseukraïns'kogo z'ïzdu ekologiv z mizhnarodnoyu uchastyu, vol. 2, pp. 362-365 (in Russian). 
3. Sakerin, S.M., Kabanov, D.M. \& Panchenko, M.V. [et al.], 2005, "Rezul'taty monitoringa atmosfernogo aerozolya $v$ aziatskoy chasti Rossii po programme AEROSIBNET $v 2004 \mathrm{~g}$. [Atmpspheric aerosol monitoring results in the Asian part of Russia according to AEROSIBNET program in 2004]”, Optika atmosfery i okeana, vol. 18, no. 11, pp. 968-975 (in Russian).

4. Ulyumdzhieva, N.N., Chubarova, N.E. \& Smirnov, A.N., 2005, "Kharakteristiki atmosfernogo aerozolya $v$ Moskve po dannym solnechnogo fotometra CIMEL [Atmospheric aerosol characteristics in Moscow according to CIMEL sun photometer], Meteorologiya i gidrologiya, no. 1, pp. 48-57 (in Russian).

5. Smirnov, A., Holben, B.N. \& Slutsker, I. [et al.], 2009, "Maritime Aerosol Network as a component of Aerosol Robotic Network", J. Geophys. Res., vol. 114, no. D06204, doi: 10.1029/2008JD011257

6. Feldman, G.C., McClain, C.R., “Ocean Color Web, SeaWiFS Reprocessing 2010.0, MODISTerra Reprocessing 2013.0, MODIS-Aqua Reprocessing 2013.1, VIIRS-SNPP Reprocessing 2014.0”, NASA Goddard Space Flight Center, Eds. N. Kuring, S.W. Bailey, http: // oceancolor.gsfc.nasa.gov/ (Access-October, 2015).

7. Sitnov, S.A., 2011, “Sputnikovyy monitoring soderzhaniy gazovykh primesey atmosfery $i$ opticheskikh kharakteristik atmosfernogo aerozolya nad evropeyskoy territoriey Rossii $v$ aprele - sentyabre $2010 \mathrm{~g}$. [Satellite monitoring of atmosphere gas admixture content and atmospheric aerosol optical characteristics over the European part of Russia in AprilSeptember 2010]”, Doklady RAN, vol. 437, no. 1, pp. 102-107 (in Russian).

8. Suslin, V.V., 1992, "Uchet atmosfernykh faktorov pri vosstanovlenii spektral'nogo koeffitsienta yarkosti otkrytogo okeana po distantsionnym izmereniyam iz kosmosa [Admittance of the atmospheric factors in the reduction of the radiance coefficient of the open ocean by remote measurements from space]”, Avtoref. dis. ... kand. fiz.-mat. nauk, Sevastopol, 20 p., http://elibrary.ru/item.asp?id=15755135 (in Russian).

9. Gordon, H.R., Wang, M., 1994, "Retrieval of water-leaving radiance and aerosol optical thickness over the oceans with SeaWiFS: A preliminary algorithm”, Appl. Opt., no. 33, pp. 443-452.

10. http://oceancolor.gsfc.nasa.gov/cms/atbd/rrs (Access-October, 2015).

11. 2014, Phytoplankton Functional Types from Space, Ed. S. Sathyendranath, Reports of the International Ocean-Colour Coordinating Group, Canada, Dartmouth, no. 15, 163 p.

12. Session "Remote Sensing of Phytoplankton Composition - Possibilities, Applications and Future Needs", Second International Ocean Colour Science Meeting (USA, San Francisco, 15 - 18 June, 2015), http://iocs.ioccg.org/program/iocs-2015-presentations/.

13. Suslin, V.V., Suetin, V.S. \& Korolev, S.N. [et al.], 2007, "Desert dust effects in the results of atmospheric correction of satellite sea color observations", Current Problems in Optics of Natural Waters: Proc. $4^{\text {th }}$ Int. Conf. (Nizhny Novgorod, September $11-15$, 2007), Nizhny Novgorod, pp. 184-187.

14. Suslin, V.V., Tolkachenko, G.A. \& Cristina, S., 2009, "Quality of the standard atmospheric products from the SeaWiFS and MODIS sensors over the Black and Mediterranean Seas", Current Problems in Optics of Natural Waters: Proc. $5^{\text {th }}$ Int. Conf. (St. Petersburg, September 8 -12, 2009), St. Petersburg, pp. 317-321.

15. http://oceancolor.gsfc.nasa.gov/cms/reprocessing (Access-October, 2015).

16. http://aeronet.gsfc.nasa.gov/new_web/Documents/version2_table.pdf (Access-October, 2015).

17. Schoeberl, M.R., Newman, P.A., 1995, “A multiple-level trajectory analysis of vortex filaments”, J. Geophys. Res., vol. 100, no. D12, pp. 25801-25815.

18. Pickering, K.E., Thompson, A.M. \& Kim H. [et al.], 2001, "Trace gas transport and scavenging in PEM-Tropics B South Pacific Convergence Zone convection”, J. Geophys. Res., vol. 106, no. D23, pp. 32591-32607.

19. http://oceancolor.gsfc.nasa.gov/VALIDATION/flags.html (Access-October, 2015). 
20. http://aeronet.gsfc.nasa.gov/cgi-bin/type_one_station_seaprism_new?site=Gloria\&nachal $=2 \& l e v e l=1 \&$ place_code=10 (Access-October, 2015).

21. http://aeronet.gsfc.nasa.gov/cgi-bin/type_one_station_seaprism_new?site=Galata_Platform\&nachal $=2 \&$ level=1\&place_code=10 (Access-October, 2015).

22. Kalinskaya, D.V., Suslin, V.V., 2015, "Prostoy metod opredeleniya istochnikov prizemnogo aerozolya na osnove rezul'tatov analiza obratnykh traektoriy [Simple method of the determination of the surface aerosol based on the analysis results of the reverse trajectories]", Fundamental'naya i prikladnaya gidrofizika, vol. 8, no. 1, pp. 59-67 (in Russian).

23. Kahn, R.A., Garay, M.J. \& Nelson, D.L. [et al.], 2007, “Satellite derived aerosol optical depth over dark water from MISR and MODIS: Comparisons with AERONET and implications for climatological studies”, J. Geophys. Res., vol. 112, no. D18205, doi: 10.1029/2006JD008175

24. Suslin, V.V., Churilova, T.Ya. \& Dzhulay, A. [et al.], “Regional'nyy algoritm vosstanovleniya kontsentratsii khlorofilla «a» i koeffitsienta pogloshcheniya sveta nezhivym organicheskim veshchestvom na dline volny $490 \mathrm{~nm} v$ Chernom more dlya spektral'nykh kanalov tsvetovykh skanerov MODIS i MERIS [Regional algorithm of chlorophyll $a$ concentration and coefficient of light absorption by detrital matter on $490 \mathrm{~nm}$ wavelength in the black sea for SEAWIFS, MODIS and MERIS bands]", Ekologicheskaya bezopasnost' pribrezhnoy $i$ shel'fovoy zon $i$ kompleksnoe ispol'zovanie resursov shel'fa, iss. 28, pp. 303-319,

http://blackseacolor.com/Site/Papers/suslinchurilova.pdf (in Russian).

25. Suslin, V.V., Churilova, T.Ya., 2015, “Trekhkanal'nyy metod razdeleniya pogloshcheniya sveta fitoplanktonom i nezhivym organicheskim veshchestvom: prilozhenie k distantsionnomu zondirovaniyu $v$ vidimom diapazone spektra [The three-channel method for separating the absorption of light by phytoplankton and non-living organic matter: application to remote sensing in the visible range of the spectrum]", Tr. VIII Mezhdunar. konf. "Sovremennye problemy optiki estestvennykh vod» (ONW'2015) (Sankt-Peterburg, 8 - 12 sentyabrya 2015 g.), Sankt-Peterburg, pp. 199-203 (in Russian). 